\title{
How Income Taxes Should Change during Recessions
}

\author{
Zachary Liscow ${ }^{1}$
}

August 2014

This paper offers recommendations for how the design of labor income taxes should change during recessions, based on a simple model of a recessionary economy in which jobs are rationed and some employees value working more than others do. The paper draws two counter-intuitive conclusions for maximizing social welfare. First, subsidize non-employment. This draws marginal workers out of the labor force, creating "space" for those who really need jobs. Second, subsidize employers for hiring, not the employees themselves. The problem during recessions is having too few jobs; subsidizing employers creates more jobs, while subsidizing employees confers benefits on those who already won the job lottery. Tax policy in the recent recession has done a poor job of following these recommendations.

\footnotetext{
${ }^{1}$ Email: zachary.liscow@yale.edu. Yale Law School, J.D. Expected 2015; Ph.D., University of California, Berkeley 2012. Thanks to George Akerlof, Anne Alstott, Alan Auerbach, Doug Bernheim, Raj Chetty, David Gamage, Jonah Gelbach, Indivar Dutta-Gupta, John Haltiwanger, Bob Hall, Matthew Halgren, Nate Hilger, Jim Hines, Caroline Hoxby, Nir Jaimovich, Pete Klenow, Jon Klick, Pat Kline, Yair Listokin, Mike Lovenheim, Enrico Moretti, Luigi Pistaferri, Steve Raphael, Emmanuel Saez, Rob Shimer, Edison Yu, and Noah Zatz for their helpful comments.
} 


\section{Contents}

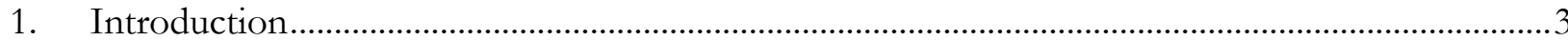

2. Contribution to Existing Literature ………................................................................................... 6

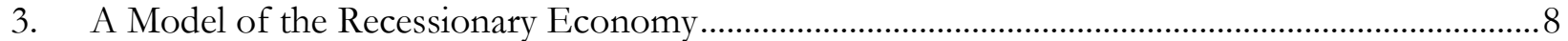

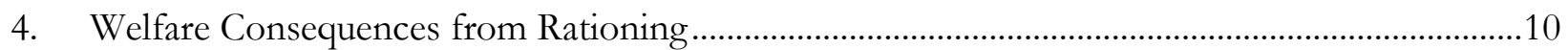

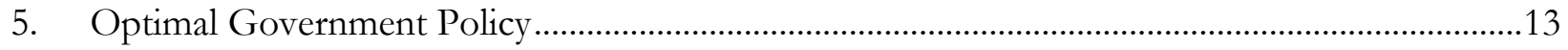

A. Recommendation 1: Subsidize Non-Employment …….............................................................13

B. Recommendation 2: Subsidize Employers for Hiring, Not the Employees ..........................16

i. Subsidizing Employers is Welfare-Increasing...................................................... 16

ii. Subsidizing Employees is Welfare-Decreasing ................................................. 18

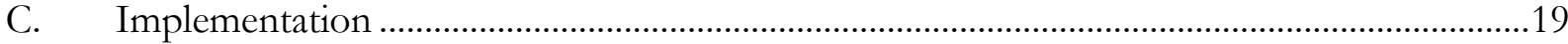

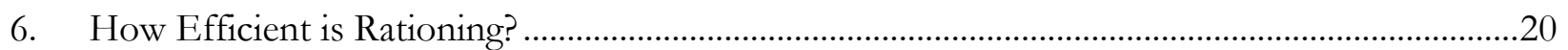

7. Considerations Outside of the Model Generally Support the Main Conclusions.........................23

8. Assessment of Policies during the Recent Downturn .....................................................................25

A. Congress Has Subsidized Non-Employment ……....................................................................25

B. Congress Has Done the Opposite of Subsidizing Employers, Not Employees ...................26

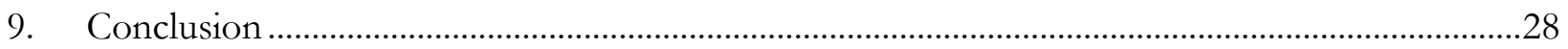




\section{Introduction}

In response to the Great Recession, the federal government has spent hundreds of billions of dollars in tax and other interventions in the labor market as part of the "stimulus" and follow-up policies. Policy-makers have traditionally based their policies on "Keynesian" theories that recessions are driven by inadequate demand, so that increasing government spending will increase demand for economic activity and workers. ${ }^{2}$ However, these theories guide how much to spend, not how to design the spending. As a result, despite this massive outlay of funds, the theory for the form that labor income taxes and related policies should change during recessions is surprisingly poorly-developed. Instead of drawing on Keynesian macroeconomic theories, I draw on the microeconomics literature on how labor markets function during recessions - in particular, the literature on matching unemployed workers with firms. ${ }^{3}$ Insights from microeconomics help answer why there are "two few" jobs and which workers gain employment.

The paper draws two conclusions for maximizing social welfare. First, subsidize nonemployment. This draws marginal workers out of the labor force, creating "space" for those who really need jobs. Second, subsidize employers for hiring, not the employees themselves. The problem during recessions is having too few jobs; subsidizing employers creates more jobs, while subsidizing employees confers benefits on those who already won the job lottery. Unfortunately, policy during and after the Great Recession has done a poor job of following these policies, possibly helping generate some of the political backlash to stimulus programs.

\footnotetext{
2 See David Romer, Advanced Macroeconomics 242-44 (2006) (for a modern rendition of the Keynesian model). Keynesian theory was originally developed in JOHN MAYNARD KEYNES, THE GENERAL THEORY OF EMPLOYMENT, INTEREST AND MONEY (1936).

${ }^{3}$ For prominent explanations of the literature on matching in unemployment, see Robert Shimer, The Cyclical Behavior of Equilibrium Unemployment and V acancies, 95 AM. ECON. REV. 25 (2005) and Arthur J. Hosios, On the Efficiency of Matching and Related Models of Search and Unemployment, REV. ECON. STUD. 279 (1990).
} 
I base these recommendations upon a novel model of the recession economy which has two

key features. First, jobs are rationed during recessions. That is, the number of people willing to work substantially exceeds the number of jobs available. Many economists believe that the job rationing comes from the fact wages fall little in recessions, generating more people who wish to work than jobs to employ them. ${ }^{4}$ Whatever the cause, high unemployment itself means that jobs must be rationed. Second, there is good reason to think that there is a substantial amount of randomness in how jobs are rationed. That is, some people really value having a job, and others do not, and there are likely insufficient mechanisms in place to ensure that the high-surplus type of worker receives the job over the low-surplus type of worker. ${ }^{5}$ For example, an individual with a mortgage to pay, a non-working spouse, and three children may really need a job; this would be a high-surplus worker. ${ }^{6}$ If rationing is

\footnotetext{
${ }^{4}$ Economists believe that jobs are rationed because wages do not fall during recessions, even though demand for workers falls, generating more workers willing to work than employers wish to employ. For economics papers arguing why rationing is an important feature of recessionary economies because wages do not change quickly enough to stop the rationing, see Truman BeWLeY Why Wages DON'T FALl DuRING A RECESSION (1999) (suggesting, based upon interviews with workers and management, that workers strongly dislike decreases in their "nominal" - that is, non-inflation-adjustedwage and that these decreases would decrease moral and therefore productivity) and John Taylor, Staggered Wage Setting in a Macro Model, 80 AM. ECON. REV. 37 (1979) (with wage stickiness, both upward and downward, resulting from the fact that firms cannot fully adjust its wages if its competitors are not adjusting theirs at the same time because of staggered wage-setting). Bewley's work builds in part on that of George Akerlof, Labor Contracts as a Partial Gift Exchange, 97 Q. J. ECON. 543 (1982) (suggesting that norms may matter in wage-setting). For recent prominent macroeconomic models which include these "wage rigidities," see Robert Hall, Employment Fluctuations with Equilibrium Wage Stickiness, 95 AM. ECON. REV. 50 (2005) (incorporating sticky wages into a search model, but assuming that the sticky wages merely adjust the division of surplus and do not generate layoffs, contrary to our model) and Robert Shimer, The Consequences of Rigid Wages in Search Models, 2 J. Eur. ECON. Ass'N 469 (2004) (adding wage rigidities to a search model with stochastic shocks and finding that, if all wages are inflexible, the model does a better of predicting the dynamics of employment throughout business cycles, but still finding that the welfare costs of the business cycle are still low). See also Robert Shimer, Convergence in Macroeconomics: The Labor Wedge, 1 AM. ECON. J.: MACROECONOMICS 280 (2009) (arguing that wage rigidities, combined with search frictions, are a promising possible explanation for unemployment during recessions). But see Christopher Pissarides, The Unemployment Volatility Pu₹zle: Is Wage Stickiness the Answer?, Walras-Bowley Lecture (2007) (arguing that wage rigidities cannot explain unemployment during recessions). This literature does not include heterogeneous reservation wages, which I explore. Finally, for econometric evidence of nominal rigidities, see James Poterba, Julio Rotemberg \& Lawrence Summers, A Tax-Based Test for Nominal Rigidities, 74 AM. ECON. REV. 659 (1986).

${ }^{5}$ The implications of heterogeneous worker surplus have been explored in other contexts. See, e.g., Bontemps, et al. $A n$ Empirical Equilibrium Job Search Model with Search on the Job and Heterogeneous Workers and Firms, 40 INT'L ECON. REV. 1039 (1999) (studying the implications of heterogeneous worker surplus on "equilibrium wage dispersion," that is how wages for similar jobs vary).

${ }^{6}$ There are many reasons that individuals may vary in their surplus from work. For example, some may particularly fear long-term earnings losses due to long-term unemployment resulting from being unemployed (related to "hysteresis," or increased unemployment resulting from prolonged periods of unemployment during economic shocks). For evidence on long-term earning losses resulting from being laid off, see Till von Wachter et al., Long-Term Earnings Losses due to Mass Layoffs During the 1982 Recession: An Analysis Using U.S. Administrative Data from 1974 to 2004, http://www.columbia.edu/ vw2112/papers/mass_layoffs_1982.pdf.
} 
inefficient, then this inefficient rationing, not the shortage of jobs per se, is the much bigger cause of social welfare loss in the economy.

These two features of the recessionary economy generate the two policy recommendations. Likewise, with randomness in rationing, one key concern is ensuring that the right type of person receives the jobs, generating the first recommendation of subsidizing non-employment to encourage marginal workers to leave the labor force and create "space" for high-valuation workers. Likewise, with rationing, another key concern is creating more jobs, not subsidizing existing workers, generating the second recommendation of subsidizing employers for employing workers, not the employees themselves. To my knowledge, asking how taxes should change during recessions with either of these assumptions, let alone both, is new to the tax literature.

I then argue that limitations of the model do not substantially affect the policy recommendations. In particular, this microeconomic model does not consider Keynesian macroeconomic goal of increasing aggregate demand. However, the best estimates of the macroeconomic stimulus of the relevant policies suggests that the policies recommended in this paper are actually some of the best for macroeconomic stimulus, so there is not a tension between the recommendations of microeconomics and microeconomics. ${ }^{7}$

Finally, the paper reviews the recent experience of labor market "taxes" in response to the Great Recession in light of the arguments presented here. The first recommendation—of subsidizing non-employment—has been followed by Congress. However, despite interest in policies consistent with this paper, the second recommendation—of subsidizing employers, not employees—has largely not been followed. To the contrary, a policy commonly-used during this and other recessions is employee-side payroll tax rebates, draws marginal workers into the labor force, decreasing social welfare

\footnotetext{
${ }^{7}$ Douglas W. Elmendorf, Policies for Increasing Economic Growth and Employment in 2012 and 2013, CONGRESSIONAL BUDGET OfFICE 28, Nov. 15, 2011, http://www.cbo.gov/sites/default/files/cbofiles/attachments/11-15Outlook_Stimulus_Testimony.pdf.
} 
by encouraging people who value work relatively little to join the competition for a fixed number of jobs that would otherwise have been sought only by people who more highly value working.

\section{Contribution to Existing Literature}

This paper contributes to several literatures. First, this paper contributes to the renewed interest in how taxes and spending should change during recessions, in light of the aftermath of the Great Recession. Prominent economists have noted that research in this area is sorely needed. ${ }^{8}$ Lawyers have started the project of understanding how tax laws should change during recessions. In particular, Yair Listokin makes a forceful argument that the lack of macroeconomic considerations in tax law is quite problematic. ${ }^{9}$ Others have begun understanding how features of the tax code, like the Alternative Minimum Tax, soften the blow of recessions and how they could do an even better job of serving that goal. ${ }^{10}$ Others have considered how unemployment insurance should vary over the business cycle. ${ }^{11}$ This is the first paper which considers the implications of efficient and inefficient job rationing on the choice between subsidizing employers, employees, and non-employment.

Second, this paper is part of a broader reassessment of the implications for tax law when traditional assumptions on the invariance of statutory incidence for economic incidence do not hold. That is, in a Coase-like way, economists traditionally have believed that it does not matter who actually remits a tax in determining who actually ends up paying for the tax after all price changes have been

\footnotetext{
8 Alan J. Auerbach, Implementing the New Fiscal Policy Activism, 99 AM. ECON. REV. 543, 548 (2009) (" []f we are going to practice fiscal discretionary policy on a large scale, then more attention to policy design is sorely needed.”)

${ }_{9}$ Yair Listokin, Equity, Efficiency, and Stability: The Importance of Macroeconomics for Evaluating Income Tax Policy, 29 YALE J. ON REG. 45 (2012).

10 Brian Galle \& Jonathan Klick, Recessions and the Social Safety Net: The Alternative Minimum Tax as a Countercyclical Fiscal Stabilizer, 63 STAN. L. REV. 187 (2010).

11 Camille Landais, Pascal Michaillat \& Emmanuel Saez, Optimal Unemployment Insurance over the Business Cycle, NBER Working Paper No. 16526 (2013) (also finding that unemployment insurance should be more generous during recessions, but based on a model which assumes that all workers value work the same amount and also not studying the choice between taxing employees or subsidizing employers or other forms of subsidizing non-employment).
} 
taking into account. ${ }^{12}$ For example, Wojciech Kopczuk, Justin Marion, Erich Muehlegger, and Joel Slemrod show that the point of collection matters for the incidence of state diesel taxes due to evasion. ${ }^{13}$ This paper shows another context in which standard assumptions about incidence are misguided — and therefore may be leading to bad policies, like subsidizing workers instead of their employers.

Third, I apply to a new context the theory on inefficient rationing. Since at least the 1940's, scholars have recognized that regulations such as rent control prevent the efficient allocation of demanders to suppliers. ${ }^{14}$ More recently, scholars have studied the inefficiencies of misallocation of workers and jobs in the context of the minimum wage. ${ }^{15}$ Studies from the gasoline, rental housing, and natural gas markets provides good evidence that regulation causes misallocation. ${ }^{16}$ I build in particular on earlier theoretical work by Edward Glaeser and Erzo Luttmer, who develop welfare analysis for the efficiency of rationing in rent-controlled housing market. ${ }^{17}$ I apply this theory for the first time to the context of labor markets during recessions ${ }^{18}$ and make the point that the market can exhibit the same problems on its own that price regulations can result in-and that similar policy solutions can apply.

\footnotetext{
${ }^{12}$ Kyle D. Logue \& Joel Slemrod, Of Coase, Calabresi, and Optimal Tax Liability, 63 TAx. L. REV. 797 (2010).

${ }_{13}$ Wojciech Kopczuk, Justin Marion, Erich Muehlegger \& Joel Slemrod, Do the Laws of Tax Incidence Hold? Point of Collection and the Pass-through of State Diesel Taxes (2013), http://www.ire.eco.usi.ch/presentazione/paper-muehlegger-203467.pdf. This builds on earlier work of Poterba et al., supra note 4.

${ }^{14}$ Milton Friedman \& George Stigler, Roofs or Ceilings? The Current Housing Problem, 2 POPULAR Essays On CuRrent ProbS. 1 (1946).

${ }^{15}$ John R. Lott, Non-transferable Rents and an Unrecognized Social Cost of Minimum Wage Laws, 11 J. LABOR ReSEARCH 453 (1990).

${ }^{16}$ Empirical evidence of misallocation due to regulation is reviewed in Erzo Luttmer, Does the Minimum Wage Cause Inefficient Rationing?, 7 B.E. J. ECON. ANALYSIS \& POL'Y (CONTRIBUTIONS) 49 (2007).

${ }^{17}$ Edward Glaeser \& Erzo Luttmer, The Misallocation of Housing under Rent Control, 93 AM. ECON. REV. 1027 (2003). A later paper by Luttmer develops a test for the efficiency of rationing in the minimum wage labor market using a test which is conceptually similar; he studies how the demographics of the workforce change as the minimum wage changes, under the principle that a higher minimum wage leads to more rationing and that some demographics are correlated with reservation wage. Luttmer, supra note 16.

${ }^{18}$ David Lee and Emmanuel Saez explore optimal minimum wage policy if the social planner values redistribution, where rationing is efficient and inefficient. David Lee \& Emmanuel Saez, Optimal Minimum Wage in Competitive Labor Markets, 96 J. PUB. ECON. 739 (2012).
} 
Finally, this paper contributes to the nascent discourse on behavioral tax law. ${ }^{19}$ In particular, it explores the implications for tax policy of the most-touted explanation for wage stickiness, norms within firms that prevent wages from decreasing during recessions. This paper combines these nonstandard preferences with their effects on the macro-economy to develop new implications for tax law.

\section{A Model of the Recessionary Economy}

In this section, I develop a basic model of a recessionary economy; policy implications follow in later sections. To make the insights most transparent, I keep the math to a minimum and relegate the details to an online appendix. Following Glaeser and Luttmer in their discussion of rent control, I consider a model with linear labor demand and supply, with labor demand given by $P^{D}=b_{D}-$ $m_{D} Q$ and labor supply given by $P^{s}=b_{s}+m_{s} Q \cdot{ }^{20}$ I also assume that employment is binary: workers are either employed or not employed, leaving aside part-time jobs or the number of hours worked. Workers have identical productivity but heterogeneous surplus from work (the difference between the actual wage level and the lowest wage level at which an individual is willing to work, which is known as the "reservation wage").

Suppose that, because a recession has just begun and wages are sticky, the wage level is some amount $\theta$ greater than the efficient market-clearing price $\left(P^{*}\right) .{ }^{21} \mathrm{I}$ do not explore the possible causes

\footnotetext{
19 See, e.g., Christine Jolls, Cass R. Sunstein \& Richard Thaler, A Behavioral Approach to Law and Economics, 50 STAN. L. REV. 1471 (1998) (describing how behavioral economics should change policy recommendations in law and economics generally), EDWARD MCCAFFERY \& JOEL SLEMrod, BEHAVIORAL PUbliC FINANCE (2006) (reviewing recent developments in behavioral economics and their implications for public finance), and Jacob Goldin \& Yair Listokin, Tax Expenditure Salience, AM. L. \& ECON. REV. (forthcoming) (describing issues that arise in tax when tax expenditures may be less salient than other expenditures).

20 Glaeser \& Luttmer, supra note 17.

${ }^{21}$ As noted above, this assumption is common in the economics literature. It is also supported by the interviews conducted by BEWLEY, supra note 4 at 241-243 (noting that no companies offered "choice between layoff and continued work on the same job at lower pay" and "[m]ost managers were astonished by the idea of offering as an alternative to layoff continued work on the same job at reduced pay."). As more time passes after the beginning of the recession and wages have time to adjust, the wage rigidities which motivate this paper become less relevant-and, therefore, so do its implications.
} 
of the stickiness, instead accepting at face value the notion that wages must be sticky to generate such large fluctuations in employment during business cycles. ${ }^{22}$ This could be because morale would be harmed too much if wages were lowered, ${ }^{23}$ because employers cannot coordinate in lowering wages, ${ }^{24}$ or other reasons. ${ }^{25}$ Effectively, the labor demand curve has shifted down, but wages do not adjust fully. (Of course, it is fine for this story if wages adjust some, such as through cuts in fringe benefits or through a gradual erosion in real wages through inflation, as long as they do not adjust fully.) As shown in Figure 1, $Q^{S}$ workers are willing to for work at this wage, but only $Q^{D}$ are employed, resulting in an excess supply of workers.

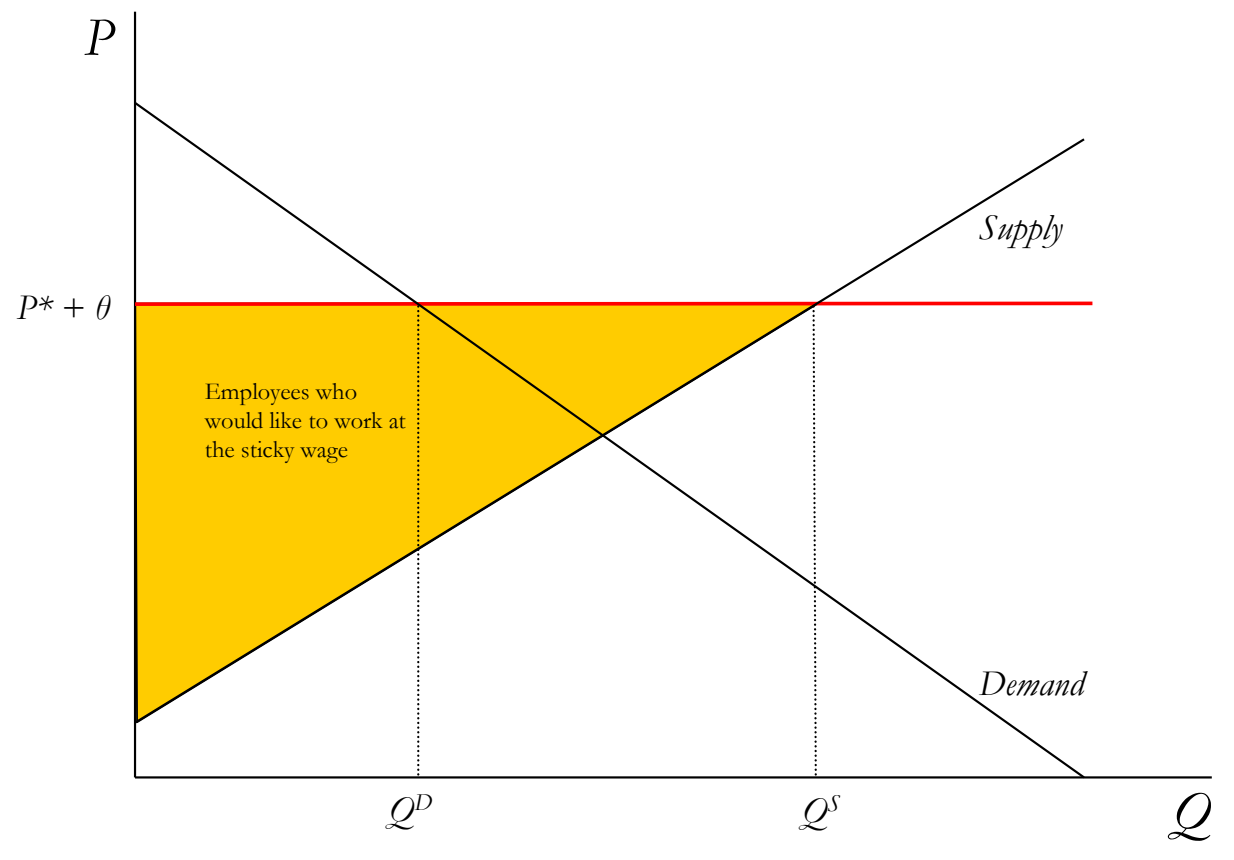

Figure 1: Employees Willing to Work at the Sticky Wage

\footnotetext{
22 See David Romer, Real Rigidities, New PAlgrave Dictionary of ECONOMics, 2nd edition (2007) and Shimer, supra note 3 ..

${ }^{23}$ BEWLEY, supra note 4.

24 Taylor, supra note 4.

${ }^{25}$ Note that the problem of sticky wages persists even as many people come and go from jobs. See Steven J. Davis \& John Haltiwanger, Gross Job Flows, in 3 HANDBOOK OF LABOR ECONOMICS 2711 (Orley Ashenfelter \& David Card, ed. 1999) (on the large flows of people into and out of jobs, even with the total number of jobs is stable). New hires are also affected by sticky wages, both to maintain intra-firm equity in wages between old and new hires, and because firms offering new jobs are competing with employers offering high "sticky" wages. See Taylor, supra note 4.
} 
I assume that workers can be rationed into jobs either efficiently or uniformly. Under "efficient rationing," the workers who value the job the most receive it. Under "uniform rationing," all workers who are willing to work at the prevailing wage have an equal probability of receiving the job. While the assumption of uniform rationing may seem extreme, it strikes seems a reasonable case to consider because firms presumably care primarily about productivity. In the absence of any pricebased incentive (or ability) for firms to distinguish between workers with higher and lower reservation wages, there may be little reason that firms would draw such distinctions. Moreover, it is difficult to imagine a Coasian bargain being struck between high-surplus unemployed individuals and low-surplus employed ones as such a bargain would have to involve the potential employers. How efficient rationing is likely to be is explored further below.

Finally, suppose that welfare can be measured by taking the area between the labor demand and supply curves, thereby adding up the employer and employee surplus. ${ }^{26}$

\section{Welfare Consequences from Rationing}

This setup yields the following proposition:

P1: The deadweight loss ("DWL," or loss to welfare) from uniform rationing, $\frac{b_{D}-b_{S}}{2 m_{D}} \theta$, is strictly higher than that the DWL from efficient rationing, $\frac{m_{D}+m_{s}}{2 m_{D}^{2}} \theta^{2} \cdot \cdot^{27}$

To gain insight into this result, I turn to graphical representations of the DWL in the two rationing regimes. Figure 2 shows the DWL in the case of efficient rationing. The deadweight loss is

\footnotetext{
${ }^{26}$ This is the case with "quasi-linear utility functions" conventionally used in economic models. This means that utility is linear in income. In other words, there are no income effects.

27 The result requires the additional natural assumption that the sticky wage is not so high that the market evaporates or so low that there is in fact no sticky wage (i.e., $\theta=0$ ).
} 
represented by $\mathrm{ABC}$, the area between the supply and demand curves for workers who would work at quantity $Q^{*}$ at the market-clearing wage but not at the sticky wage. Area $\mathrm{ABC}$ is a standard a Harberger triangle, the familiar way of measuring DWL in economics. ${ }^{28} \mathrm{I}$ call this triangle the "quantity DWL."

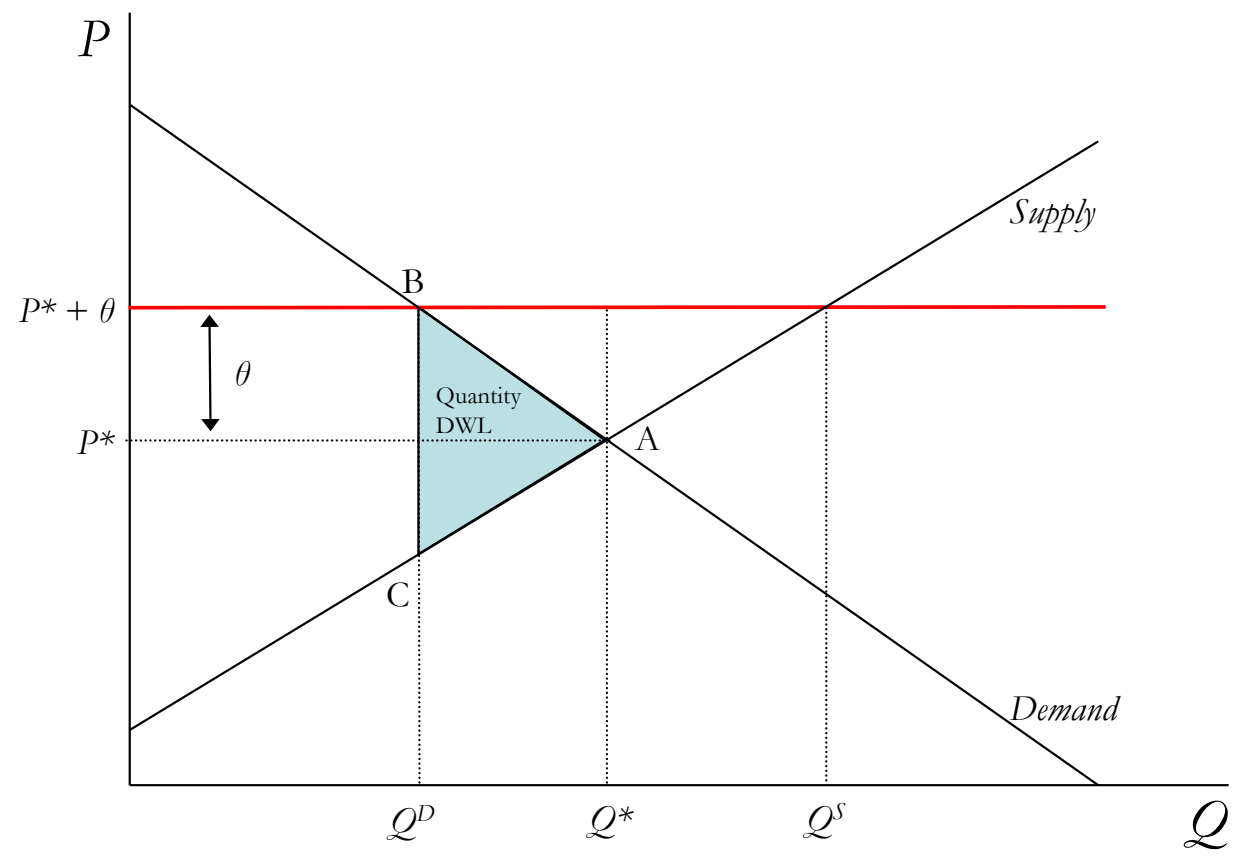

Figure 2: Deadweight Loss from Sticky Wages and Efficient Rationing

Uniform rationing results in the same quantity DWL plus an additional DWL resulting from the misallocation of workers to jobs. I call this additional DWL the "allocative DWL," and it is represented by area CDEF in Figure 3. In the efficient rationing case, the worker surplus is the area from the wage to the supply curve. In the uniform case, the worker surplus only constitutes the area

${ }^{28}$ Arnold C. Harberger, The Measurement of Waste, 43 AM. ECON. REV. 58 (1964) (deriving the triangle method of analyzing deadweight loss) and Arnold C. Harberger, Taxation, Resource Allocation, and Welfare, in THE ROLE OF DIRECT AND INDIRECT TAXES IN THE FEDERAL REVENUE SYSTEM 25 (John F. Due ed., 1964) (applying the triangle method to estimate deadweight losses due to income taxes in the United States). See also James R. Hines, Three Sides of Harberger Triangles, $13 \mathrm{~J}$. ECON. PERSP. 167 (1999) (providing additional and more contemporary explanations of Harberger triangles). 
from the wage down to the average reservation wage of workers willing to work at this wage. Willing workers have a higher average reservation wage than just the subset of willing workers with the lowest reservation workers (i.e., with the highest surplus from work). (Note that a lower reservation wage means higher worker surplus.) The allocative DWL is large because the first individual rationed out of a job is the average individual willing to work at the sticky wage, who is not indifferent between working and not working. ${ }^{29}$

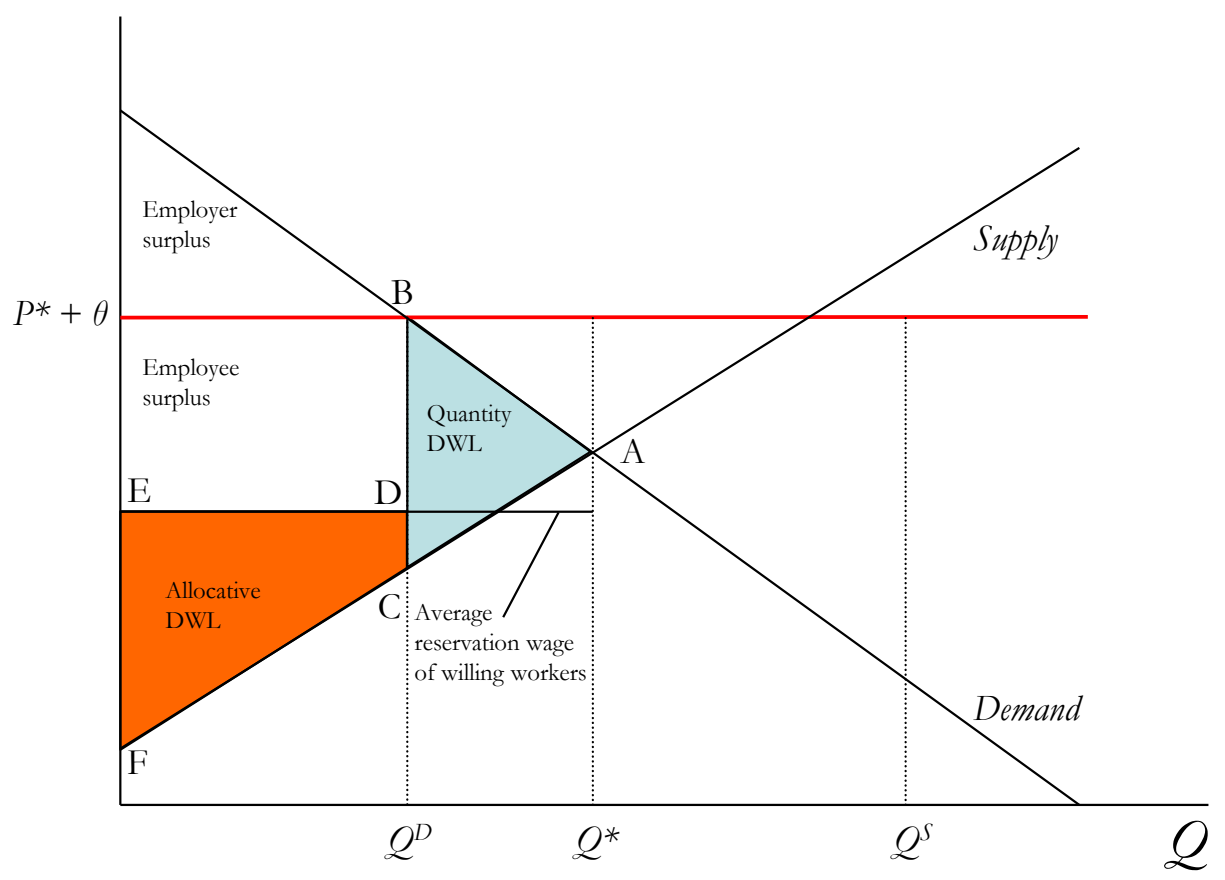

\section{Figure 3: Deadweight Loss from Sticky Wages and Uniform Rationing}

Furthermore, the concern here about rationing efficiency is not a trivial one. Quite to the contrary, for small amounts of wage stickiness, the main problem is not that there are too few jobs,

\footnotetext{
${ }^{29}$ Technically, the DWL is first-order in $\theta$ for uniform rationing and second-order in $\theta$ for efficient rationing. See infra note 34 for an explanation of "first-order" and "second-order."
} 
resulting in quantity DWL, but rather that the wrong workers are in the jobs that exist. ${ }^{30}$ The intuition is simple: suppose that there is just a small amount of rationing, such that there is only one excess worker. The quantity deadweight loss is tiny (indeed, infinitesimally small); that worker was close to the margin of working anyways, so there is very little loss to him or his employer from his not being able to work. But if rationing is uniform, then the one worker who cannot find a job may be one who really needed the job-indeed, on average, it will be the willing worker with the average surplus from working as shown in Figure 3. The loss to this worker is very large.

\section{Optimal Government Policy}

Here I consider two labor market policies that can help alleviate the DWL during recessions. For simplicity I assume that all government policy is financed by non-distortionary lump-sum taxes.

\section{A. Recommendation 1: Subsidize Non-Employment}

The first result from this set-up is:

P2: In the case of uniform rationing, a subsidy for non-employment causes a large welfare gain. ${ }^{31}$

Consider a subsidy for non-employment, like an increase in unemployment insurance or a welfare program like Temporary Assistance for Needy Families. As shown in Figure 4, labor supply

\footnotetext{
${ }^{30}$ More technically, $\lim _{\theta \rightarrow 0}\left(\frac{D W L \text { under uniform rationing- } D W L \text { under efficient rationing }}{D W L \text { under efficient rationing }}\right)=\infty$. That is, the limit as $\theta$ approaches 0 of the ratio of 1) the extra DWL from uniform rationing relative to efficient rationing and 2) the DWL from efficient rationing alone is infinite. For small amounts of rationing, all that matters is the inefficient rationing, not the jobs shortage. ${ }^{31}$ In particular, for subsidy $W$, the welfare gain is $\frac{1}{2}\left(P^{*}+\theta-\left(b_{S}+m_{S} \frac{(\theta-W)\left(m_{S}+m_{D}\right)+m_{S}\left(b_{D}-b_{S}\right)}{m_{S}\left(m_{S}+m_{D}\right)}\right)\right) Q^{*}$. The welfare gain is "large" in the sense of being a "first-order" welfare gain; that is, $W$ appears in the equation without being multiplied by itself. Since economic welfare analysis is done "on the margin" (i.e., for the first infinitesimally small unit of $W$ ) and when $W$ is less than 1, multiplying $W$ by itself (i.e., a "second-order" welfare gain) yields a product less than $W$ itself, the welfare gain is considered large for first-order welfare gains. An additional technical (and sensible) assumption for the marginal welfare gain to be positive is that the subsidy is not so gigantic that it reduces the number of workers willing to work to less than $Q^{D}$, the level of employment with no intervention.
} 
shifts up since having a job is relatively less valuable. Under efficient rationing this policy has no impact on DWL. Regardless of the subsidy, the individuals gaining the most from the job are employed. However, with uniform rationing and no subsidy, many employed workers receive little surplus from their employment. A subsidy for non-employment induces those with the least surplus to exit the labor force, creating "space" for workers with a higher surplus from work. Figure 4 shows the reduced allocative DWL (CD'E'F) if labor supply changes to Supply 2 , decreasing the average reservation wage of those employed by removing marginal workers from the labor force. Indeed, the allocative DWL can be eliminated if the subsidy is raised enough that workers are only willing to supply $Q^{D}$ of labor. Intuitively, what happens is that a worker who values working at almost nothing is replaced by the average unemployed worker, who actually values working quite a lot, substantially increasing social welfare.

With uniform rationing there is an obvious welfare-enhancing trade to be made: people who value working highly but who were not hired should pay those who value working only a small amount but who were hired to give up their jobs. A subsidy for non-employment mimics this payment system. 


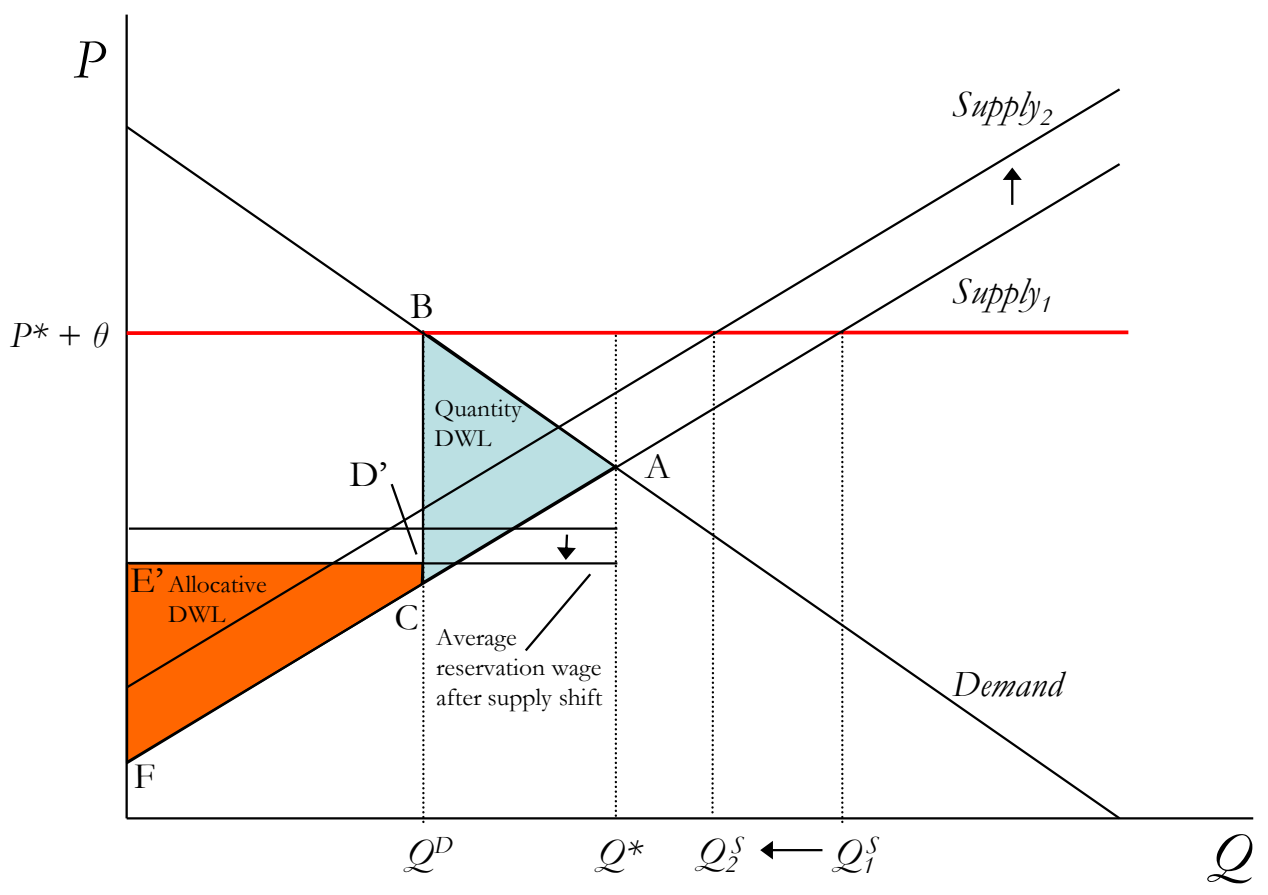

Figure 4: Subsidizing Non-employment

A corollary of the result that subsidizing non-employment increases social welfare is that policies that discourage marginal individuals from seeking work and competing with those who really need jobs are also beneficial. So policy-makers should consider making it easier for individuals to stay eligible for social insurance programs rather than returning to jobs that they do not wish to take. For example, federal regulations provide that a jobless worker collecting unemployment insurance must search for work, but may limit his search to jobs that constitute "suitable work." 32 If an unemployed worker refuses to accept "suitable work" without suitable cause, he loses unemployment insurance benefits. The surplus of jobs and presence of some workers who want them more than others suggest that, during recessions, suitable work standards should be weakened—-that is, the definition of work that is considered "suitable" should be narrowed. As a result, unemployed individuals would not need

3220 C.F.R. S 604.5. For additional discussion, see Redefining "Suitable-Work" and Job-Search Rules for Unemployment Insurance, NAtional Employment LaW PROJECt 1 (2012). 
to pursue and accept jobs that they do not want very much just to maintain their unemployment insurance, making both the individual not forced to take the job and the individual who actually gets the job better off. Another condition of eligibility for unemployment insurance is the "prevailing conditions" test, allowing unemployment insurance recipients to refuse jobs that fall below prevailing market conditions as determined by the overall labor market, rather than worker's own skills as for the suitable work requirements. ${ }^{33}$ Weakening this test during recessions would also help ensure that those who most need jobs receive them. Similar reasoning applies to social insurance programs from supplemental income for food to health care: during recessions, eligibility should be expanded so that unemployed individuals need not seek out and accept jobs that they value little when there are many others who highly value those jobs.

\section{B. Recommendation 2: Subsidize Employers for Hiring, Not the Employees}

i. $\quad$ Subsidizing Employers is Welfare-Increasing

Second, consider a subsidy which pays employers for each of the employees that they employ and the following result:

P3: In rationed labor markets, a hiring subsidy for employers increases welfare. ${ }^{34}$

As shown in Figure 5, suppose that the subsidy increases labor demand to Demand2. Because of the subsidy, employers hire more workers, and the quantity DWL shrinks from the large area $\mathrm{ABC}$ in

\footnotetext{
${ }^{33}$ Federal Unemployment Tax Act, $\int 3304(\mathrm{a})(5)(B)$. See also Unemployment Insurance Program Letter No. 41-98, U.S. DEPARTMENT OF LABOR, Aug. 17, 1998.

${ }^{34}$ In particular, the welfare gain for subsidizing an employer is $\frac{1}{2}\left(P^{*}+\theta-b_{S}-W\right) \frac{W}{m_{D}}$. While still positive, the welfare gain starts decreasing when the subsidy is greater than half the surplus of the highest-surplus worker (that is, the total welfare benefits start declining when $\left.W>\frac{P^{*}+\theta-b_{S}}{2}\right)$. Put another way, for large employer-side subsidies, in which the marginal dollar in employer subsidy causes little decrease in quantity DWL, a marginal increase in the subsidy can increase total DWL, so employer subsidies should be set below this point.
} 
Figure 3, with no employer subsidy, to the smaller area $A B$ "C" in Figure 5, with the subsidy. Essentially, a key problem in rationed labor markets is that employers provide too few jobs. Subsidizing employers to hire more workers alleviates this problem. Because sticky wages cause employers to pay "too much" for workers, the fact that the subsidy goes to employers, not employees, is key, since the subsidies reduce the wage that employers pay. If the subsidy had gone to workers, there would have been no decline in the amount that employers had to pay their workers.

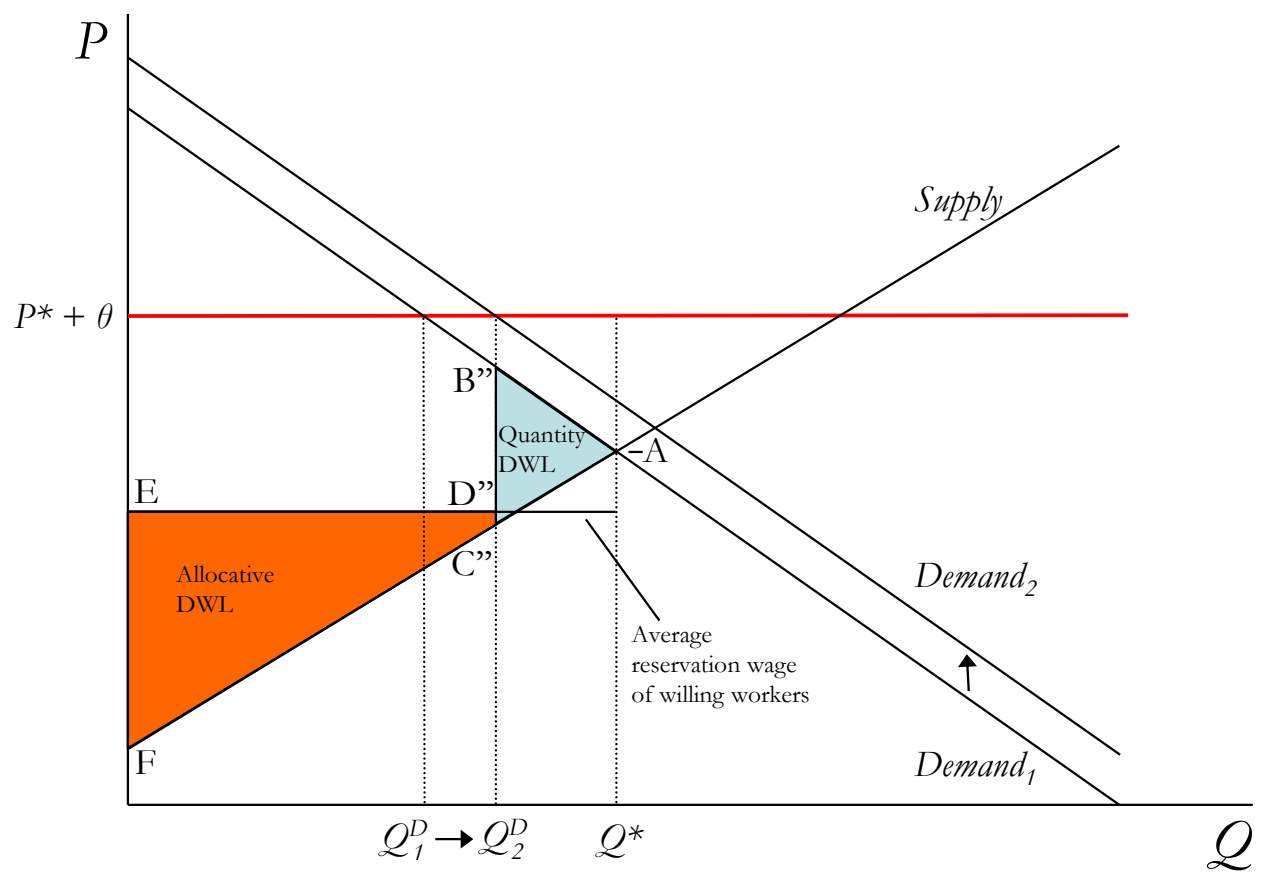

Figure 5: Employer Subsidy with Uniform Rationing

Although the analysis in this paper generally assumes that rationing is uniform, note that this result does not depend upon the efficiency of the rationing, since the gain in efficiency comes from quantity DWL, not allocative DWL. Quantity DWL is the same under either type of rationing. Rather, subsidizing employers can actually be less valuable under uniform rationing than under efficient rationing. The reason is that, with uniform rationing, the allocative inefficiency (area C'D”EF) grows with the subsidy in some cases, as shown in Figure 5, with the extension of allocative DWL to the 
right even as quantity DWL shrinks to the right. ${ }^{35}$ The rationale is simple: although more workers are employed, some of those gaining employment do not value their jobs very much, increasing allocative inefficiency. In other words, some of the loss in quantity DWL is "taken back" by an increase in allocative DWL. Nevertheless, under either form of rationing, an employer subsidy is a welfareimproving policy.

\section{ii. Subsidizing Employees is Welfare-Decreasing}

Now consider a subsidy for employees, instead of employers. This is exactly the opposite of Recommendation 1, subsidizing non-employment, since subsidies for employees make nonemployment less attractive, not more attractive. This yields the following proposition:

P4: In the case of uniform rationing, a subsidy for employees decreases welfare. ${ }^{36}$

When considering a subsidy for employees, the analysis in Figure 4 for subsidizing non-employment reverses. When workers decide whether to enter the labor market, they compare their utility from entering the labor market with their utility from exiting the labor market. Thus, this policy draws more marginal workers into the labor force, by making working more attractive. However, it does not increase the number of jobs, like subsidizing employers. These marginal workers then compete with workers who really need jobs, the opposite of what happens with the subsidy for nonemployment. The presence in the labor market of workers who care only a little about working makes it less likely that those who really want to work will get hired at one of a fixed number of jobs.

\footnotetext{
${ }^{35}$ In particular, when the average reservation wage of workers willing to work is greater than that of the worker who would be rationed into employment under efficient rationing (the employee at $Q_{2}{ }^{D}$ along the supply curve), a marginal increase in the subsidy increases allocative DWL.

36 Thus, the welfare loss from subsidizing an employee is simply the negative of the welfare gain from subsidizing nonemployment. See the results in supra note 31.
} 
Therefore, these tax cuts are counterproductive with uniform rationing as they aggravate the allocative DWL without reducing the quantity DWL. ${ }^{37}$ This result of subsidizing employers instead of employees resonates with the political debate during the recession on the importance of "creating" more jobs; the focus was not on helping out workers who already were lucky enough to have jobs.

\section{Implementation}

The two policies recommended here-subsidizing non-employment and subsidizing employers during recessions_could be enacted in at least two ways. First, Congress could add "triggers" to the tax code and welfare programs in which these policies go into effect if unemployment passes a certain threshold, say seven percent. To my knowledge, neither the tax code nor welfare programs currently contain such triggers. Such triggers would have the advantage of coming into effect without delay from Congress. They would have the disadvantage of potentially generating perverse strategic behavior. For example, suppose that this trigger policy has been adopted and the unemployment rate is creeping toward seven percent as an employer debates whether to hire a temporary employee now or in a few months. The employer may delay hiring new employees until he can get a wage subsidy from the government, potentially exacerbating the very problem the employer-side subsidies are designed to solve. ${ }^{38}$ Alternatively, Congress could adopt new laws as times of economic stress arise, as was done in the most recent recession. This policy has the advantage of allowing Congress to tailor the policies the specific contemporaneous circumstances, but the disadvantage of delay_ or potentially no action at all.

\footnotetext{
${ }^{37}$ Instead of subsidizing employees, the model actually implies that it is desirable to increase taxes on employees. Of course, raising taxes during recessions is a bad idea for macroeconomic reasons. If it were wise, though, taxing employees and subsidizing employers would effectively reduce the post-tax wage, removing the underlying source of inefficiency and therefore reducing both allocative and quantity DWLs. Although the market will not get the wage down, the government can effectively decrease it. Such a policy is an alternative to inflation when the Federal Reserve already has interest rates as low as they can go, which happened in the most recent recession.

38 Congress could partially respond to the concern about employers' strategic behavior by promising during its deliberations to make the subsidy retroactive.
} 


\section{How Efficient is Rationing?}

In this section, I argue that it is reasonable to think that job rationing during recessions is inefficient. ${ }^{39}$ To understand how efficient rationing is during recessions, one must consider the two main sources of unemployment_layoffs and lack of hiring. ${ }^{40}$ Each can potentially have a different mechanism which bears on the efficiency of rationing. I will review each type in turn.

First, evidence suggests that how much workers value the job is not a criterion considered by firms in making layoff decisions. In particular, when Yale economist Truman Bewley interviewed firms about their layoff decisions, there was no evidence at all that this was a concern. ${ }^{41}$ This apparent indifference makes sense because firms care about productivity, not worker surplus from work. Indeed, evidence from Bewley and others confirms that productivity is an important criterion when considering whom to lay off. ${ }^{42}$ As well, even if firms did care, it would be difficult for them to distinguish between workers with high and low surplus from work; presumably, many workers would profess having a high surplus in order to help them keep their jobs. ${ }^{43}$ Furthermore, in some cases, firms do not even choose individual workers to layoff and instead lay off whole divisions or close entire plants. In those cases, of course there can be no attention paid to worker surplus. Indeed, Bewley concludes, "Despite the widespread use of the performance criterion, the population of unemployed was probably not of low quality, for many firms laid off whole departments or large

\footnotetext{
${ }^{39}$ Measuring rationing efficiency is particularly challenging given the unobservability of surplus from work. One approach to measuring surplus from work is using the amount that individuals say that they value working (as in Martin Feldstein \& James Poterba, Unemployment Insurance and Reservation Wages, 23 J. PuB. ECON. 141 (1984)); however, economists tend to be skeptical of such stated values, versus those that are revealed by individuals' behavior.

${ }^{40}$ In principle, people who quit but do not find employment could also be a part of unemployment. However, evidence shows that the number of people quitting jobs actually went down substantially during the recession, so quits are unlikely to play an important role in cyclical unemployment. In contrast, layoffs increased substantially and the number of job opening and amount of hiring plummeted, making it harder to find jobs. See Job Opening and Labor Turnover Point to (Slow) Recovery, http://econompicdata.blogspot.com/2011/11/job-opening-and-labor-turnover-point-to.html (last visited Aug. 1, 2014).

41 BEWLEY, supra note 4, at 238-242.

42 See, e.g., Robert Gibbons \& Lawrence Katz, Layoffs and Lemons, 9 J. LABOR ECON. 351 (1991) (confirming empirical predictions of a model in which low-productivity workers are laid off when firms do not close whole plants and therefore have discretion over layoffs).

${ }^{43}$ Of course, family circumstances and other things may be observed, but these are likely to be crude proxies.
} 
portions of them." ${ }^{44}$ Thus, the best evidence suggests that, on the layoff side, employer behavior does not undermine the assumption of uniform rationing; firms lay off whole plants or divisions or they pay attention to productivity, not worker surplus. ${ }^{45}$

Evidence from the hiring side also suggests that inefficient rationing may be rampant. As with layoffs, there is no evidence that firms considered workers' surplus in hiring. Bewley's research reveals no attempt to hire those with higher surplus from work. ${ }^{46}$ But there is a second side to hiring-worker effort into getting hired. Likely, the ability of workers who have a higher surplus from employment to work hard at getting a job partly undoes part of what otherwise might be inefficient rationing. However, the evidence from Bewley and others suggests that even significant search effort or flexibility by the unemployed often did not yield a job during a recession. ${ }^{47}$

Indeed, though not framed as inefficient job rationing, the kind of luck that generates inefficient rationing is implicit in a great deal of economic modeling on how workers search for jobs. Although these models range from quite simple ${ }^{48}$ to very complex, ${ }^{49}$ all recognize that in finding (and often losing) a job, there is an element of chance. Plants close, interviews go poorly, unlucky social networks of friends, and stochastic rapport between interviewer and firm all cause otherwise identical individuals to face different outcomes in the labor market. In fact, there is a large empirical literature

\footnotetext{
44 BEWLEY, supra note 4, at 238.

45 Some firms also lay off in reverse seniority, which also is unlikely to closely correspond to workers surplus from work. Id.

${ }^{47}$ BEWLEY, supra note 4 at 341 ("I asked whether people could find work quickly if they were sufficiently flexible and energetic in their job search. The answer was usually an emphatic 'no.' Respondents claimed that the general shortage of jobs and the overqualification problem made finding a job of any time a long, difficult process, though some job hunters were lucky. The shortage of jobs relative to the number of job seekers preoccupied advisers of the unemployed. . . All but one of these 18 said it normally took a long time to find work, even if job searchers were energetic and completely flexible.") See also Alan B. Krueger \&Andreas Mueller, Job Search and Unemployment Insurance: New Evidence from Time Use Data, IZA DP No. 3667, 24 http:/ / anon-ftp.iza.org/dp3667.pdf (2008) (finding in the most basic model that "increasing [job] search by one hour increases the probability of finding a job by 0.31 percentage points," which the authors consider "small").

48 John McCall, Economics of Information and Job Search, 84 Q. J. ECON. 113 (1970).

49 Fabien Postel-Vinay \& Jean-Marc Robin, 2002, Equilibrium Wage Dispersion with Worker and Employer Heterogeneity, 70 ECONOMETRICA 2295 (2002) (taking into account worker and firm heterogeneity).
} 
suggesting that workers who lose their jobs for plausibly exogenous reasons, such as firm closures, experience substantially worse labor market outcomes. ${ }^{50}$ This literature emphasizes that there is a random component to labor market outcomes. My model rests on the assumption that finding and keeping a job is partly a random process.

Additional support for inefficient job rationing during recessions-combining hiring and layoffs_comes from the problematic results when one ignores such assumptions. Famously, Nobel laureate Robert Lucas built an economic model which found that recessions should have only small consequences for social welfare. ${ }^{51}$ That is, aggregate happiness should not be affected much by recessions. This conclusion may not fit with intuitions that recessions are very important and cause great hardship and definitely do not fit with the political attention afforded recessions. A key part of the reason for his conclusion is that all members of the economy are identical in Lucas's model, removing the possibility that some individuals who particularly would like to work are not able to. ${ }^{52}$ Thus, implicitly assuming efficient rationing helps lead to results which seem wrong.

One potential critique of the existence of inefficient rationing is that workers and employers should take advantage of the Coase theorem to arrive a mutually-beneficial bargain. For example, among similar workers, those with high surplus could pay workers with low surplus to resign, "leaving a space" for the high-surplus worker in the face of layoffs. Or an unemployed high-surplus individual could pay an unemployed low-surplus individual not to apply for a rationed job. Bewley observed no such bargains, and I can find no evidence that others do either. ${ }^{53}$ Social norms or coordination failures might prevent side-deals which might otherwise take place. Alternatively, it could be that one worker

\footnotetext{
${ }^{50}$ Louis S. Jacobson, Robert J. LaLonde \& Daniel G. Sullivan. Earnings Losses of Displaced Workers, 83 AM. ECON. REv. 685. (1993).

${ }^{51}$ RoBert LuCAS, MOdels OF Business CyCles (1987).

${ }^{52}$ Lucas also implicitly assumes that every individual has perfect insurance against fluctuations in income. Combining heterogeneous surplus from work and inefficient rationing together provides a reason that imperfect insurance would yield particularly large welfare losses: some of those losing jobs (and therefore consumption) during recessions are those most in need.

${ }^{53}$ BEWLEY, supra note 4,
} 
could pay another to quit, but that the quitter may save another person's job, not that of he who paid. That is, it may be difficult to coordinate side-payments.

\section{Considerations Outside of the Model Generally Support the Main Conclusions}

The model developed in this paper is, of course, limited by its assumptions. However, even looking outside the model, other considerations are generally supportive of the paper's conclusions. One important consideration outside of this model is the policy's effect on aggregate demand. ${ }^{54}$ In particular, one might be concerned that subsidizing employers instead of employees would put money in the hands of those who are less likely to spend it (i.e., they have a lower "marginal propensity to consume"), resulting in less spending and therefore less aggregate demand, harming economic recovery. Fortunately, the best evidence suggests that the growth effects of the policies recommended here are also policies with large effects on aggregate demand. ${ }^{55}$ In particular, among the thirteen options considered by the Congressional Budget Office for increasing economic growth, the two with the largest impact on GDP per dollar of spending were increasing aid to the unemployed (expected to increase GDP by $\$ 1.15$ per dollar of spending), a form of subsidizing non-employment, and reducing employers’ payroll taxes (expected to increase GDP by $\$ 0.75$ per dollar of spending), a hiring subsidy for employers. Reducing employees' payroll taxes, thereby subsidizing employment on the employee side, was expected to have a smaller impact, at $\$ 0.50$ per dollar of spending. ${ }^{56}$ Thus, the

\footnotetext{
${ }^{54}$ For a useful summary of recent theory on Keynesian economic policies, see Jordi Gali, Modern Perspectives on Fiscal Stabilization Policies, 51 CESIFO ECON. STUD. 587 (2005) (summarizing the New Keynesian perspective on increasing aggregate demand in recessions).

${ }^{55}$ Elmendorf, supra note 7. The table actually gives ranges. I take the average of the top and bottom of the range.

${ }^{56}$ Perhaps part of the reason that the CBO makes these findings is the significant amount of stress businesses were under, perhaps increasing the likelihood that they would spend the money rather than save it.
} 
concern that increasing employment and making sure that the right employees are employed would harm economic growth appears to be unfounded based on the best available evidence.

The so-called "social costs of queueing" is a second factor not considered in the preceding analysis; it bolsters the first policy recommendation of subsidizing non-employment. ${ }^{57}$ Suppose that when jobs are over-subscribed, anyone who wishes to gain employment must participate in a lottery and pay some fixed cost like waiting in line, interviewing, or mailing applications. On the one hand, these costs can decrease DWL by ensuring that extremely marginal individuals do not bother applying. On the other hand, the more people spending time applying for a fixed number of jobs, the more social waste results from the queueing process. A program to subsidize non-employment through unemployment or welfare payments could reduce these costs by reducing the extent to which jobs are over-subscribed; as such, the above analysis may actually understate the value of non-employment subsidies.

A third relevant factor not considered in the model is the distortion to behavior which results from the government's need to raise funds to pay for government programs. Of course, this factor does not alter the recommendation of subsidizing firms instead of workers. However, it does affect the value of subsidizing non-employment. ${ }^{58}$ In particular, if I added considerations of the costs of taxation, the cost of subsidizing employers and non-employment would be understated.

Of course, the model used in this paper ignores other potentially important considerations, including hiring and firing costs, heterogeneity across sectors of the economy, the possibility of targeting based on observables ${ }^{59}$, and changes over time (i.e., "dynamics”). The model assumes a fixed

\footnotetext{
57 Yoram Barzel, $A$ Theory of Rationing by Waiting, 17 J.L. \& ECON. 73 (1974).

58 Note that this cost would be the same under efficient and inefficient sorting.

${ }^{59}$ David Neumark, Spurring Job Creation in Response to Severe Recessions: Reconsidering Hiring Credits, 32 J. POL'Y ANALYSIS \& MGMT. 142 (2013).
} 
wage; to the extent that workers' wages respond to the reservation wage, fall in a recession, or change with subsidies, the results will be less relevant.

\section{Assessment of Policies during the Recent Downturn}

\section{A. Congress Has Subsidized Non-Employment}

The first policy recommendation that I make is that effective subsidies on the non-employed should go up during recessions. Congress has followed this recommendation. Most importantly, Congress has repeatedly extended increases in the generosity of unemployment insurance. ${ }^{60}$ At an estimated cost of $\$ 39$ billion, the approximately $\$ 800$ billion American Recovery and Reinvestment Act (also known as the Obama stimulus or "the Recovery Act") increased weekly unemployment payouts by $\$ 25$, suspended income taxation on the first $\$ 2,400$ of benefits in 2009 , and extended the duration of unemployment insurance by 13 weeks. ${ }^{61}$ Benefits similar to these were extended through shortly before the end of 2013. ${ }^{62}$ Evidence suggests that these unemployment extensions did, indeed, keep people out of the labor force. ${ }^{63}$

The Recovery Act included many other provisions effectively subsidizing non-employment as well. First, Act increased the subsidies for health insurance through former employers for the

\footnotetext{
${ }^{60}$ Julie M. Whittaker \& Katelin P. Isaacs, Extending Unemployment Compensation Benefits During Recessions, CONGRESSIONAL RESEARCH SERVICE, May 2, 2013, http://www.fas.org/sgp/crs/misc/RL34340.pdf (listing the numerous extensions of unemployment insurance through May 2013) [hereinafter Whittaker \& Isaacs, Extending Unemployment Compensation]; Julie M. Whittaker \& Katelin P. Isaacs, Unemployment Insurance: Programs and Benefits, CONGRESSIONAL RESEARCH SERVICE, Feb. 12, 2014, https://www.fas.org/sgp/crs/misc/RL33362.pdf (on unemployment insurance extension through nearly the end of 2013) [hereinafter, Whittaker \& Isaacs, Unemployment Insurance].

${ }^{61}$ American Recovery and Reinvestment Act of 2009, Pub. L. No. 111-5, Division B, Title II, Subtitle A. For a description, see Clinton T. Brass, et al., American Recovery and Reinvestment Act of 2009 (P.L. 111-5): Summary and Legislative History, CONGRESIONAL RESEARCH SERVICE $\quad 29, \quad$ Apr. 20,2009 , http://waxman.house.gov/sites/waxman.house.gov/files/documents/UploadedFiles/ARRA.pdf, and Whittaker \& Isaacs, Extending Unemployment Compensation, supra note 59, at 24.

${ }^{62}$ Whittaker \& Isaacs, Unemployment Insurance, supra note 59. On the expiration of benefits at the end of 2013, see Ed O'Keefe, Unemployment benefits dominate the agenda, WASH. POST, Jan. 31, 2014, http://www.washingtonpost.com/politics/unemployment-benefits-dominate-the-agenda/2014/01/31/3a63a70a-865911e3-b85b-b305db87fb90_story.html.

${ }^{63}$ Jesse Rothstein, Unemployment Insurance and Job Search in the Great Recession, 2011 BROOKINGS PAPERS ON ECON. ACTIVITY 143 (2011).
} 
unemployed (known as "COBRA") ${ }^{64}$, at an estimated cost of $\$ 25$ billion. ${ }^{65}$ The Supplemental Nutritional Assistance Program and other expenditures to pay for food for very low-income or unemployed individuals were also expanded, at a cost of over $\$ 20$ billion. ${ }^{66}$ This provision makes it easy to have no income and in fact requires that as a condition. Likewise, the Recovery Act included funding for states to maintain their Temporary Assistance for Needy Families payments (the program after the mid-1990s “welfare reform”), estimated at a cost of $\$ 18.5$ billion. ${ }^{67}$ Finally, the Act provided an estimated $\$ 88$ billion in funding for state governments, conditioned on their maintaining the standards in Medicaid, the program which provides health care to low-income individuals, many of whom are not employed. ${ }^{68}$

\section{B. Congress Has Done the Opposite of Subsidizing Employers, Not Employees}

Policy during the recession has been inconsistent with the second policy recommendation, to subsidize employers instead of employees. Although President Obama has at least twice proposed substantial credits to employers for hiring new workers ${ }^{69}$, Congress has only enacted one tiny and one small credit. The tiny credit was in the Recovery Act and provided an estimated $\$ 231$ million $^{70}$ for

\footnotetext{
${ }^{64}$ Consolidated Omnibus Budget Reconciliation Act of 1985 (COBRA). Pub.L. 99-272, 100 Stat. 82.

65 Pub. L. No. 111-5, Division B, Title III. For a description, see Brass et al., supra note 61, at 29 \& 32-33.

${ }^{66}$ Pub. L. No. 111-5, Division A, Title I. For a description, see Brass et al., supra note 61, at 14.

${ }^{67}$ Pub. L. No. 111-5, Division B, Title II, Subtitle B. For a description, see Brass et al., supra note 61, at 31

68 Pub. L. No. 111-5, Division B, Title V. For a description, see Brass et al., supra note 61, at 35 \& 45 . See also Cliff Binder et al., American Recovery and Reinvestment Act of 2009 (ARRA, P.L. 111-5): Title V, Medicaid Provisions, CONGREssionAL RESEARCH SERVICE, Mar. 17, 2009, http://assets.opencrs.com/rpts/R40223_20090317.pdf.

${ }^{69}$ The first was a campaign promise that "[d] uring 2009 and 2010, existing businesses will receive a $\$ 3,000$ refundable tax credit for each additional full-time employee hired." The Obama-Biden Plan, http://change.gov/agenda/economy_agenda/, accessed Feb. 24, 2014. Second, in January 2010, President Obama proposed the Small Business Jobs and Wages Tax Cut, which would provide business with “a \$5,000 tax credit for every net new employee that they employ in 2010," capped at $\$ 500,000$ per firm and with half the tax credit allowed for start-ups. It also would have reimbursed "[s]mall businesses that increase[d] wages or hours for their existing employees . . . for the Social Security payroll taxes they pa[id] on real increases in their payrolls." Firms would have been "able to claim the credit on a quarterly basis, ... [to get] money out to businesses quickly and provides and [sic] early incentive to hire and increase payrolls." President Obama to Propose New Small Business Jobs and Wages Tax Cut, WHITE House, Jan. 28, 2010,

http:/ /www.whitehouse.gov/the-press-office/president-obama-propose-new-small-business-jobs-and-wages-tax-cut.

70 The American Recovery and Reinvestment Act of 2009: Full Summary of Provisions from Senate Finance, House Ways \& Means Committees, U.S. House of Representatives Ways And Means CommitTee 4, Feb. 12, 2009, http://waysandmeans.house.gov/media/pdf/111/arra.pdf.
} 
hiring tax credits for hiring unemployed veterans and unskilled younger workers. ${ }^{71}$ The small credit came in the Hiring Incentives to Restore Employment (HIRE) Act, enacted on March 18, 2010, which provided an estimated $\$ 13$ billion in subsidies to employers who hired certainly previously unemployed workers. $^{72}$ In the context of the approximately $\$ 1$ trillion spent during and after the Recovery Act, these expenditures are quite small.

Instead, Congress has passed policies contrary to the recommendations in this paper. In particular, Congress passed employee-side payroll tax reductions. The Recovery Act included the "Making Work Pay Tax Credit," a refundable tax credit of up to $\$ 400$ for individuals and $\$ 800$ for married couples in 2009 and $2010 .^{73}$ The credit was available up to $6.2 \%$ of earned income and phased out for high-income tax payers. ${ }^{74}$ The credit was estimated to cost $\$ 116.2$ billion, about ten times the estimated cost of the HIRE Act. ${ }^{75}$ Furthermore, similar tax reductions were extended into

\footnotetext{
${ }^{71}$ Pub. L. No. 111-5, Division B, Title I, $\ 1221$. For a description of the provision, see IRS Offers Tax Credit Guidance to Businesses Hiring Unemployed Veterans and Certain Youth, Internal Revenue Service, May 28, 2009, http://www.irs.gov/uac/IRS-Offers-Tax-Credit-Guidance-to-Businesses-Hiring-Unemployed-Veterans-and-CertainYouth.

${ }^{72}$ H.R. 2847. The Act provided two benefits to employers: "The first, referred to as the payroll tax exemption, provides employers with an exemption from the employer's 6.2 percent share of social security tax on wages paid to qualifying employees, effective for wages paid from March 19, 2010 through December 31, 2010. In addition, for each qualified employee retained for at least 52 consecutive weeks, businesses will also be eligible for a general business tax credit, referred to as the new hire retention credit, of 6.2 percent of wages paid to the qualified employee over the 52 week period, up to a maximum credit of $\$ 1,000 . " \quad H I R E$ Act: Questions and Answers for Employers, http://www.irs.gov/Businesses/SmallBusinesses-\&-Self-Employed/HIRE-Act:--Questions-and-Answers-for-Employers. See also Baucus Hails Final Passage of Job-Creation Legislation, https: $/ /$ www.google.com $/$ url?sa $=\mathrm{t} \& \mathrm{rct}=\mathrm{j} \& \mathrm{q}=\&$ esrc $=\mathrm{s} \&$ source= $=\mathrm{web} \& \mathrm{~cd}=12 \& \mathrm{cad}=\mathrm{rja} \& \mathrm{ved}=0 \mathrm{CDIQFjABOAo \& url}=\mathrm{h}$ ttp $\% 3 \mathrm{~A} \% 2 \mathrm{~F} \% 2 \mathrm{Fwww}$. finance.senate.gov $\% 2 \mathrm{Fdownload} \% 2 \mathrm{~F} \% 3 \mathrm{Fid} \% 3 \mathrm{D} 4 \mathrm{dfdaafa}-7 \mathrm{eaa}-4 \mathrm{e} 49-903 \mathrm{a}-$ ce6f45159fd8\&ei=aNhdUtHAKve34APvsYDgCQ\&usg=AFQjCNHMXF3CMiaHUsApOzPcq1Xe1gkLQ\&sig2=Ikoo5tTen2hCEVciemGEvQ.

73 Pub. L. No. 111-5, Division B, Title I, Subtitle A; Brass et al., supra note 61.

${ }^{74}$ In particular, it "phase[d] out for taxpayers with modified adjusted gross income in excess of $\$ 75,000$, or in the case of married couples filing jointly, $\$ 150,000 . ”$ Brass et al., supra note 61, at 36 .

${ }^{75} I d$.
} 
$2011^{76}$, at an estimated cost of $\$ 112^{77}$ and into 2012 at a similar cost. ${ }^{78}$ Thus, the $\$ 13$ billion in employer-side subsidies for employment enacted by Congress are dwarfed by the over $\$ 330$ billion in employee-side subsidies. This paper suggests that this spending was a misuse of funds, drawing marginal workers into a fixed number of a jobs and making it harder for those who really needed to work to find employment. The policy choice is all the more remarkable given that the best evidence on the effects of employer-side subsidies on employment, from a program in the 1970s, was very favorable. $^{79}$

\section{Conclusion}

Recessions cause a tremendous amount of suffering. Many people are out of work, and some of them really need jobs. The government typically steps in to help alleviate this spending, sometimes with massive expenditures. Yet, at least in the recent downturn, the response was widely-believed to have fallen short, despite this great expense. This paper identifies part of why the response might have fallen short in the arena of labor income tax policy and how to improve tax policy next time around.

The paper makes two, perhaps counter-intuitive, recommendations for how to do so. First, subsidize non-employment. This draws marginal workers out of the labor force, creating "space" for those who really need jobs. Second, subsidize employers, not employees. The recommendations

\footnotetext{
76 Tax Relief, Unemployment Insurance Reauthorization, and Job Creation Act of 2010, P.L. 111-312. For a description of the 2011 payroll tax reduction, see Dawn Nuschler, Social Security: Temporary Payroll Tax Reduction, CONGRESSIONAL RESEARCH SERVICE, January 9, 2012, http://assets.opencrs.com/rpts/R41648_20120109.pdf .

${ }^{77}$ Tax Relief, Unemployment Insurance Reauthorization, and Job Creation Act of 2010: Information Center, http://www.irs.gov/uac/Tax-Relief,-Unemployment-Insurance-Reauthorization,-and-Job-Creation-Act-of-2010:Information-Center.

${ }^{78}$ The payroll tax cut was first extended two months, through February 2012. H.R. 3630, Temporary Payroll Tax Cut Continuation Act of 2011. For description see Payroll Tax Cut Temporarily Extended into 2012, http://www.irs.gov/uac/Payroll-Tax-Cut-Temporarily-Extended-into-2012. Then, in February 2012, it was extended for the rest of the year with the Middle Class Tax Relief and Job Creation Act of 2012, Pub. L. No. 112-96. The estimated cost of the 10-month extension was $\$ 93.2$ billion. Summary of The Middle Class Tax Relief and Job Creation Act of 2012, Feb. 16,2012 ,

http://www.finance.senate.gov/newsroom/chairman/release/?id=c42a8c8a-52ad-44af-86b2-4695aaff5378.

${ }^{79}$ Jeffrey M. Perloff \& Michael L. Wachter, The New Jobs Tax Credit: An Evaluation of the 1977-78 Wage Subsidy Program, 69 AM. ECON. REV. 173 (1979).
} 
accord with empirical evidence on the effectiveness of jobs programs and with common intuitions about the problems with the economy; the main problem during the recession downturn was not that pay is too low for those who have jobs, but rather that employers created too few jobs. The policies are also among those that cause the most macroeconomic stimulus. Hopefully, with greater understanding of the basic economics underlying tax policy during recessions, politicians can overcome the poor optics of subsidizing non-employment and employers and increase employment for those who most need jobs during the next economic downturn. 


\title{
Online Appendix to "How Income Taxes Should Change
}

\section{During Recessions"}

\author{
August 7, 2014
}

\section{Model Set-up}

This section describes the key features of the labor market, solves for the competitive equilibrium without distortions, and calculates the social surplus from employment. There is a unit mass of potential workers and a unit mass of firms. Potential workers choose to work or not work. Workers have costs from employment that are distributed uniformly from $b_{S}$ to some large cost, $m_{S}+b_{S} \cdot{ }^{1}$ Symmetrically, firms have benefit from employment that are distributed uniformly from $b_{D}-m_{D}$ to some large benefit $b_{D}$. Throughout, I assume that the market-clearing wage will be such that some workers and some firms are unmatched; there is always a reserve of potential workers and potential employers.

The uniformity assumption gives rise to linear aggregate supply and demand curves. Labor demand is therefore is given by

$$
P^{D}=b_{D}-m_{D} Q
$$

\footnotetext{
${ }^{1}$ For variables related to workers (labor suppliers), we use the abbreviation $S$. For variables related to employers (labor demanders), we use the abbreviation $D$. As will become clear below, the variables $b_{S}$ and $b_{D}$ refer to the intercepts of the labor supply and demand curves, while the variables $m_{S}$ and $m_{D}$ refer to the slope of the labor supply and demand curves.
} 
Similarly, labor supply is also linear and given by

$$
P^{S}=b_{S}+m_{S} Q .
$$

I make several innocuous parametric assumptions:

- $b_{D}, b_{S}>0$ (The most eager individuals (firms) would be willing to accept (pay) a positive amount for employment.)

- $b_{D}>b_{S}$ (The intercept of the demand curve is greater than the intercept of the supply curve.)

- $m_{D}, m_{S}>0$ (The demand (supply) curve slopes downward (upward).)

In a free market equilibrium, I have demand equal to supply. This implies that

$$
\begin{aligned}
P^{D} & =P^{S} \\
b_{D}-m_{D} Q & =b_{S}+m_{S} Q \\
b_{D}-b_{S} & =Q\left(m_{D}+m_{S}\right)
\end{aligned}
$$

or that

$$
Q^{*}=\frac{b_{D}-b_{S}}{m_{D}+m_{S}} .
$$

Plugging in the equilibrium price to the supply curve, I have

$$
\begin{aligned}
P^{*} & =b_{S}+m_{S} Q^{*} \\
& =\frac{b_{D} m_{S}+m_{D} b_{S}}{m_{D}+m_{S}}
\end{aligned}
$$


The social surplus is the area between the supply and demand curves. In general this would be

$$
\text { Social Surplus }=\int_{0}^{Q^{*}}\left[P^{D}(Q)-P^{S}(Q)\right] d Q .
$$

Here, the form is especially easy because it is a triangle. The social surplus in the free market economy is

$$
\begin{aligned}
\text { Social Surplus } & =\frac{1}{2} Q^{*}\left(b_{D}-b_{S}\right) \\
& =\frac{1}{2} \frac{b_{D}-b_{S}}{m_{D}+m_{S}}\left(b_{D}-b_{S}\right) \\
& =\frac{\left(b_{D}-b_{S}\right)^{2}}{2\left(m_{D}+m_{S}\right)} .
\end{aligned}
$$

The above results applied to a free market flexible price equilibrium. For the remainder of the Appendix, I assume that wages are sticky, so that actual wages $P^{A}=P^{*}+\theta$, for $0 \leq \theta$.

\section{Results}

\subsection{Proposition 1: DWL from Uniform Rationing}

The DWL from efficient rationing is second-order in $\theta$ and is given by $\frac{m_{D}+m_{S}}{2 m_{D}^{2}} \theta^{2}$.

To determine how much labor is demanded at $P^{A}$, I use the labor demand equation. I denote this 
quantity $Q^{D}$.

$$
\begin{aligned}
P^{A} & =P^{*}+\theta=b_{D}-m_{D} Q \\
& \Longrightarrow \\
Q^{D} & =\frac{b_{D}-\theta-P^{*}}{m_{D}} \\
& =\frac{b_{D} m_{D}-m_{D} b_{S}-m_{D} \theta-m_{S} \theta}{m_{D} m_{S}+m_{D}^{2}} .
\end{aligned}
$$

I then solve for the price that would cause the labor supplied to be equal to $Q^{D}$ :

$$
\begin{aligned}
P^{L} & =b_{S}+m_{S} Q^{D} \\
& =\frac{b_{D} m_{D} m_{S}-m_{D} m_{S} \theta+m_{D}^{2} b_{S}-m_{S}^{2} \theta}{m_{D} m_{S}+m_{D}^{2}} .
\end{aligned}
$$

The DWL associated with the sticky wages is given by the standard Harber triangle bounded b the demand curve, the supply curve, and the quantity demanded at $P^{*}+\theta$. The DWL is therefore equal to:

$$
\begin{aligned}
& \frac{1}{2} \cdot \underbrace{\left[P^{*}+\theta-P^{L}\right]}_{\text {Base of triangle: difference in price }} . \underbrace{\left[Q^{*}-Q^{D}\right]}_{\text {Height of triangle: difference in quantity }} \\
= & \frac{1}{2} \cdot\left[\frac{b_{D} m_{S}+m_{D} b_{S}}{m_{D}+m_{S}}+\theta-\frac{b_{D} m_{D} m_{S}-m_{D} m_{S} \theta+m_{D}^{2} b_{S}-m_{S}^{2} \theta}{m_{D} m_{S}+m_{D}^{2}}\right] . \\
& {\left[\frac{b_{D}-b_{S}}{m_{D}+m_{S}}-\frac{b_{D} m_{D}-m_{D} b_{S}-m_{D} \theta-m_{S} \theta}{m_{D} m_{S}+m_{D}^{2}}\right] } \\
= & \frac{m_{D}+m_{S}}{2 m_{D}^{2}} \theta^{2} .
\end{aligned}
$$

The DWL from uniform rationing is first-order in $\theta$ and is given by $\frac{b_{D}-b_{S}}{2 m_{D}} \theta$.

To determine the DWL, I calculate the surplus of the employers and the workers under this system and subtract from the free market case. Employer surplus is given by the triangle under the demand 
curve and above the sticky wage, $P^{*}+\theta$. The triangle has a height of $b_{D}-\left(P^{*}+\theta\right)$ and a base of $Q^{D}$

$$
\begin{aligned}
\text { Employer Surplus } & =\frac{1}{2}\left(b_{D}-\left(P^{*}+\theta\right)\right) \cdot Q^{D} \\
& =\frac{\left(m_{D} b_{S}-b_{D} m_{D}+m_{D} \theta+m_{S} \theta\right)^{2}}{2\left(m_{D}+m_{S}\right)^{2} m_{D}} .
\end{aligned}
$$

Second, I find welfare for the employees. The employee surplus is more complicated to compute. If every worker who wanted a job were hired, the surplus would be given by the triangle given by the points (in $(Q, P)$ space) $\left(0, b_{S}\right),\left(0, P^{*}+\theta\right)$, and $\left(Q^{S}, P^{*}+\theta\right)$. To solve for $Q^{S}$, the measure of workers that would want to work at the binding minimum wage, I use the supply curve.

$$
\begin{aligned}
P^{A} & =b_{S}+m_{S} Q \\
& \Longrightarrow \\
Q^{S} & =\frac{P^{*}+\theta-b_{S}}{m_{S}} \\
& =\frac{b_{D} m_{S}-b_{S} m_{S}+m_{D} \theta+m_{S} \theta}{m_{D} m_{S}+m_{S}^{2}} .
\end{aligned}
$$

The area of this triangle defined by $\left(0, b_{S}\right),\left(0, P^{*}+\theta\right)$, and $\left(Q^{S}, P^{*}+\theta\right)$ is

$$
\begin{aligned}
& \frac{1}{2} \cdot\left(P^{*}+\theta-b_{S}\right) \cdot\left(Q^{S}\right) \\
= & \frac{\left(b_{D} m_{S}-b_{S} m_{S}+m_{D} \theta+m_{S} \theta\right)^{2}}{2\left(m_{D}+m_{S}\right)^{2} m_{S}} .
\end{aligned}
$$

However, since the measure of firms that would like to hire a worker at the price $P^{*}+\theta$ is $Q^{D}$ and the measure of workers willing to work is $Q^{S}$, with the uniform rationing, each worker would would like 
to work is employed with probability $Q^{D} / Q^{S}$. Hence the employee surplus is given by

$$
\begin{aligned}
& \frac{Q^{D}}{Q^{S}} \frac{\left(b_{D} m_{S}-b_{S} m_{S}+m_{D} \theta+m_{S} \theta\right)^{2}}{2\left(m_{D}+m_{S}\right)^{2} m_{S}} \\
= & \frac{\left(b_{S} m_{S}-b_{D} m_{S}-m_{D} \theta-m_{S} \theta\right)\left(m_{D} b_{S}-b_{D} m_{D}+m_{D} \theta+m_{S} \theta\right)}{2\left(m_{D}+m_{S}\right)^{2} m_{D}}
\end{aligned}
$$

To calculate the DWL, I first find the total social surplus, which is the sum of the employee and employer surplus. It is therefore

$$
\begin{aligned}
& \underbrace{\frac{\left(m_{D} b_{S}-b_{D} m_{D}+m_{D} \theta+m_{S} \theta\right)^{2}}{2\left(m_{D}+m_{S}\right)^{2} m_{D}}}_{\text {Employer Surplus }}+\underbrace{\frac{\left(b_{S} m_{S}-b_{D} m_{S}-m_{D} \theta-m_{S} \theta\right)\left(m_{D} b_{S}-b_{D} m_{D}+m_{D} \theta+m_{S} \theta\right)}{2\left(m_{D}+m_{S}\right)^{2} m_{D}}}_{\text {Employee Surplus }} \\
& =\frac{\left(m_{D} b_{S}-b_{D} m_{D}+m_{D} \theta+m_{S} \theta\right)\left(b_{S}-b_{D}\right)}{2\left(m_{D}+m_{S}\right) m_{D}} \text {. }
\end{aligned}
$$

DWL is therefore the difference between the total surplus in the free market case and here.

$$
\begin{aligned}
D W L(\theta) & =\underbrace{\frac{\left(m_{D} b_{S}-b_{D} m_{D}+m_{D} \theta+m_{S} \theta\right)\left(b_{S}-b_{D}\right)}{2\left(m_{D}+m_{S}\right) m_{D}}}_{\begin{array}{c}
\text { Social Surplus, Free Market } \\
\frac{\left(\left(b_{D}-b_{S}\right)^{2}\right.}{2\left(m_{D}+m_{S}\right)}
\end{array}} \\
& =\frac{\left.b_{\text {Social Surplus, Random Rationing }}-b_{S}\right) \theta}{2 m_{D}} .
\end{aligned}
$$

The DWL from uniform rationing is strictly higher than that the DWL from efficient rationing, all $\theta \in\left(0, \theta_{\max }\right)$, where $\theta_{\max }$ is defined below.

First, I restrict to cases in which the sticky wage is not so high that the market evaporates or so low that there is in fact no sticky wage. This is equivalent to stipulating that $\theta \in\left(0, \frac{\left(b_{D}-b_{S}\right) m_{D}}{\left(m_{D}+m_{S}\right)}\right)$. Let $\theta_{\max }=\frac{\left(b_{D}-b_{S}\right) m_{D}}{\left(m_{D}+m_{S}\right)}$.

I wish to calculate: 


$$
\begin{aligned}
\Delta D W L(\theta) & =[\mathrm{DWL}, \text { random sorting }]-[\mathrm{DWL}, \text { efficient sorting }] \\
& =\frac{\left(b_{D}-b_{S}\right) \theta}{2 m_{D}}-\frac{\left(m_{D}+m_{S}\right) \theta^{2}}{2 m_{D}^{2}} \\
& =-\frac{\left(m_{D} b_{S}-b_{D} m_{D}+m_{D} \theta+m_{S} \theta\right) \theta}{2 m_{D}^{2}}
\end{aligned}
$$

First note that, $\Delta D W L(0)=\Delta D W L\left(\theta_{\max }\right)=0$. Next find:

$$
\begin{aligned}
\Delta D W L^{\prime}(\theta) & =\frac{\partial\left(-\frac{\left(m_{D} b_{S}-b_{D} m_{D}+m_{D} \theta+m_{S} \theta\right) \theta}{2 m_{D}^{2}}\right)}{\partial \theta} \\
& =-\frac{m_{D} b_{S}-\left(b_{D} m_{D}+2 m_{D} \theta+2 m_{S} \theta\right.}{2 m_{D}^{2}}
\end{aligned}
$$

Note that

$$
\begin{aligned}
\Delta D W L^{\prime \prime}(\theta) & =\frac{\partial\left(-\frac{m_{D} b_{S}-b_{D} m_{D}+2 m_{D} \theta+2 m_{S} \theta}{2 m_{D}^{2}}\right)}{\partial \theta} \\
& =-\frac{m_{D}+m_{S}}{m_{D}^{2}}<0
\end{aligned}
$$

Recall that $m_{D}, m_{S}>0$ by assumption (the demand and supply curves must slope the correct way). Hence we know that $\Delta D W L^{\prime \prime}(\theta)<0 ; \Delta D W L(\theta)$ is strictly concave. Since $\Delta D W L(0)=$ $\Delta D W L\left(\theta_{\max }\right)=0$, and since the function is strictly concave, we know that $\Delta D W L(\theta)>0$ for all $\theta \in\left(0, \theta_{\max }\right)$

\subsection{Proposition 2: Subsidy for Non-Employment}

First consider a subsidy for non-employment. Suppose that the government gives a subsidy of $W$ to an individual if and only if he does not work. Suppose that $W$ is not so large so as to make the quantity of workers willing to supply labor less than $Q^{D}$. That is, the subsidy does not influence the 
measure of employed workers.

To find the total surplus, I need to add together the employer surplus and employee surplus, as above. Note that the utility of workers is unaffected by the fact that non-employment is subsidized, so the lump-sum transfer to the non-employed does not factor directly into the welfare calculations. Since employer surplus is unchanged, I only need to calculate employee surplus.

To do this, note that the surplus is the measure of workers who are employed times their average surplus. The measure of employees is $Q^{D}$, and the average surplus is the average surplus of workers willing to work up to $Q_{2}^{S}$ (see Figure 4). Given the uniform sorting, this surplus is the average of $P^{*}+\theta-b_{S}$ (the largest surplus) and $P^{*}+\theta-P_{2}^{S}$, where $P_{2}^{S}$ is the price at which $Q_{2}^{S}$ workers would be willing to work under Supply . To find $P_{2}^{S}$, plug $Q_{2}^{S}$ into Supply : $_{1}$

$$
\begin{aligned}
& P^{S}=b_{S}+m_{S} Q_{2}^{S} \\
& P_{2}^{S}=b_{S}+m_{S} \frac{(\theta-W)\left(m_{S}+m_{D}\right)+m_{S}\left(b_{D}-b_{S}\right)}{m_{S}\left(m_{S}+m_{D}\right)}
\end{aligned}
$$

Similarly, to find $Q_{2}^{S}$ :

$$
\begin{aligned}
P & =b_{S}+W+m_{S} Q \\
& \Longrightarrow \\
Q_{2}^{S} & =\frac{P^{*}+\theta-b_{S}-W}{m_{S}} \\
& =\frac{(\theta-W)\left(m_{S}+m_{D}\right)+m_{S}\left(b_{D}-b_{S}\right)}{m_{S}\left(m_{S}+m_{D}\right)}
\end{aligned}
$$


Thus the employee surplus with $W$ is

$$
\begin{aligned}
& \frac{1}{2}\left(\left(P^{*}+\theta-b_{S}\right)+\left(P^{*}+\theta-P_{2}^{S}\right)\right) Q^{D} \\
= & \frac{1}{2}\left(P^{*}+\theta-b_{S}+P^{*}+\theta-\left(b_{S}+m_{S} \frac{(\theta-W)\left(m_{S}+m_{D}\right)+m_{S}\left(b_{D}-b_{S}\right)}{m_{S}\left(m_{S}+m_{D}\right)}\right)\right) Q^{D}
\end{aligned}
$$

where $P_{2}^{S}$ is found by plugging $Q_{2}^{S}$ into the supply equation.

For comparison, find the employee surplus without $W$ using the same method. Note that this is just the quantity supplied times the average reservation wage, which is in turn, the average between 1) the surplus of the highest-reservation-wage individual and 2) the surplues of the lowest surplus individual who is employed (0):

$$
=\frac{1}{2}\left(P^{*}+\theta-b_{S}\right) Q^{D}
$$

Thus, the difference is:

$$
\begin{aligned}
& \underbrace{\frac{1}{2}\left(P^{*}+\theta-b_{S}+P^{*}+\theta-\left(b_{S}+m_{S} \frac{(\theta-W)\left(m_{S}+m_{D}\right)+m_{S}\left(b_{D}-b_{S}\right)}{m_{S}\left(m_{S}+m_{D}\right)}\right)\right) Q^{D}}_{\text {Employee Surplus, } W} \\
& -\underbrace{\frac{1}{2}\left(P^{*}+\theta-b_{S}\right) Q^{D}}_{\text {Employee Surplus, No } W} \\
= & \frac{1}{2}\left(P^{*}+\theta-\left(b_{S}+m_{S} \frac{(\theta-W)\left(m_{S}+m_{D}\right)+m_{S}\left(b_{D}-b_{S}\right)}{m_{S}\left(m_{S}+m_{D}\right)}\right)\right) Q^{*}>0 .
\end{aligned}
$$

Note that this is first-order in $W$. 


\subsection{Proposition 3: Subsidy for Employers}

Now, consider the case of subsidizing employers. In this case, welfare for both employers and employees changes. The amount of the transfer payments $W$ must also be subtracted off the change in welfare.

First, employer surplus is the area formed by the triangle with corners $\left(0, P^{*}+\theta\right),\left(0, b_{D}+W\right)$, and $\left(Q_{2}^{D}, P^{*}+\theta\right)$. This equals

$$
\frac{1}{2}\left(b_{D}+W-P^{*}-\theta\right) Q_{2}^{D}
$$

To find $Q_{2}^{D}$, substitute $P^{*}+\theta$ into Demand $_{2}$ :

$$
\begin{aligned}
P^{D} & =b_{D}-m_{D} Q \\
P^{*}+\theta & =b_{D}+W-m_{D} Q \\
& \Longrightarrow \\
Q_{2}^{D} & =\frac{b_{D}+W-P^{*}-\theta}{m_{D}}
\end{aligned}
$$

Next, find the employee surplus, which equals the measure employees times the average surplus (which is the same as the case without $W$ ):

$$
\frac{1}{2}\left(P^{*}+\theta-b_{S}\right) Q_{2}^{D}
$$

The transfer then equals the measure employed times the size of the transfer, $W$. Thus, total welfare with $W$ is

$$
\underbrace{\frac{1}{2}\left(b_{D}+W-P^{*}-\theta\right) Q_{2}^{D}}_{\text {Employer surplus }}+\underbrace{\frac{1}{2}\left(P^{*}+\theta-b_{S}\right) Q_{2}^{D}}_{\text {Employee surplus }}-\underbrace{W Q_{2}^{D}}_{\text {Transfer }}
$$

To find the change in welfare with the employer subsidy, subtract welfare in the no-subsidy case, 
yielding

$$
\begin{aligned}
& \underbrace{\frac{1}{2}\left(b_{D}+W-P^{*}-\theta\right) Q_{2}^{D}-\frac{1}{2}\left(b_{D}-P^{*}-\theta\right) Q_{1}^{D}}_{\text {Change in employer surplus with } W}+\underbrace{\frac{1}{2}\left(P^{*}+\theta-b_{S}\right)\left(Q_{2}^{D}-Q_{1}^{D}\right)}_{\text {Change in employee surplus with } W}-\underbrace{W Q_{2}^{D}}_{\text {Transfer }} \\
= & \frac{1}{2}\left(P^{*}+\theta-b_{S}-W\right) \frac{W}{m_{D}}>0 .
\end{aligned}
$$

However, note that a marginal increase in the subsidy can lead to a marginal increase in DWL when $W$ is large:

$$
\begin{aligned}
& \frac{\partial\left(\frac{1}{2}\left(P^{*}+\theta-b_{S}-W\right)\left(\frac{W}{m_{D}}\right)\right)}{\partial W} \\
= & \frac{1}{2 m_{D}}\left(P^{*}+\theta-b_{S}-2 W\right) \\
> & 0 \text { if and only if } W<\frac{P^{*}+\theta-b_{S}}{2}
\end{aligned}
$$

which means that the subsidy is not greater than half the surplus of the highest-surplus worker $\left(P^{*}+\theta-b_{S}\right)$

\subsection{Proposition 4: Subsidy for Employees}

Now, consider the case in which there is a subsidy employees. In this case, the total surplus is the sum of employer surplus, employee surplus, and the transfer from workers to the government. However, note that, given the money metric utility, total welfare is the same if the government and if the workers have it. Thus, given that this is just the reverse of the non-employment subsidy case, the change in total surplus is just the opposite of the non-employment subsidy case. 